\title{
Pelatihan Pemanfaatan Teknologi Google Drive dan Blogs bagi Pengawas Sekolah Dasar
}

\author{
Erpidawati ${ }^{1}$, Novelti*2 \\ ${ }^{1}$ Administrasi Rumah Sakit, Fakes, Universitas Muhammadiyah Sumatera Barat \\ 2Pendidikan Bahasa Indonesia, FKIP, Universitas Muhammadiyah Sumatera Barat \\ Email: Erpidawati821@gmail.com ${ }^{1}$, bundonovelti@gmail.com²
}

\begin{abstract}
In the world of education, we must quickly obtain information and be fast in sending the requested information. Indonesia is one of the developing countries that is trying to take advantage of this digitization system. With the digitization system, it is hoped that it will make it easier to send and convey information to relevant agencies in need. This activity is carried out with the aim of providing training and technical implementation so that school supervisors can take advantage of supporting media and provide useful new knowledge. The method used in this community service is the seminar method. The results obtained after this activity were that the participants were able to apply google drive and create blogs independently, in turn, and under supervision. The conclusion of the research results is that school supervisors get new knowledge, are able to operate and create google drives and blogs, understand that adding data storage patterns and data management can be done easily and efficiently.
\end{abstract}

Keywords: Utilization of Google Drive, Blogs

\section{Abstrak}

Dalam dunia pendidikan, kita harus cepat memperoleh informasi serta cepat pula dalam mengirimkan informasi yang diminta. Indonesia adalah salah satu negara yang sedang berupaya memanfaatkan sistem digitalisasi. Dengan sistem digitalisasi diharapkan akan mempermudah pengiriman dan penyampaian informasi kepada dinas terkait yang membutuhkan. Kegiatan ini dilakukan dengan tujuan memberikan pelatihan maupun teknis penggunaaan google drive dan blogs sehingga pengawas sekolah dapat memanfaatkan media pendukung dan pengetahuan baru. Metode yang digunakan dalam pengabdian masyarakat ini adalah metode seminar. Hasil yang didapat setelah dilakukannya kegiatan ini adalah peserta mampu mengaplikasikan google drive serta membuat blog secara mandiri, bergantian, dan dalam pengawasan. Simpulan hasil penelitian ialah pengawas sekolah dapat pengetahuan baru, mampu mengoperasikan dan membuat google drive serta blog, memahami bahwa penambahan pola, susunan, dan pengelolaan penyimpan data dapat dilakukan secara mudah dan efisien.

Kata Kunci: Pemanfaatan Google Drive, Blogs

\section{PENDAHULUAN}

Sebagai salah satu sumber acuan dalam pengembangan profesional tenaga kependidikan (khususnya guru), penting diefektifkan dimensi kompetensi supervisi akademik oleh pengawas. Pengawas merupakan orang atau pun instansi yang melaksanakan kegiatan supervisi terhadap guru. Dengan memaksimalkan kegiatan supervisi akademik diharapkan tenaga guru dapat meningkatkan pengetahuan dan keterampilannya dalam proses pembelajaran. Supervisi akademik merupakan kegiatan terencana yang ditujukan pada aspek kualitatif sekolah dengan membantu guru melalui evaluasi pada proses belajar dan pembelajaran agar dapat meningkatkan kualitas proses serta hasil belajar

Hasil penelitian Ruswenda (2011:114) menunjukkan bahwa ada persoalan dalam kegiatan penyusunan program, laporan hasil pengawasan, kegiatan pembinaan, pemantauan, penilaian, kegiatan pembimbingan, dan pelatihan profesionalitas guru, karena tidak sesuai dengan pedoman tugas pengawasan. Faktor penyebabnya adalah motivasi, komitmen, dan kemampuan pengawas rendah, komunikasi tidak lancar, upaya pemberdayaan, kompleksitas, 
beban kerja pengawas berat, dan budaya sekolah tidak mendukung. Begitu juga dengan tingkat profesionalisme dan frekuensi dalam malaksanakan supervisi akademik (Hubullah, 2012). Dalam rangka pemberdayaan pengawas sekolah untuk meningkatkan penjaminan mutu pendidikan, Darjat (2008:vi) membuktikan dalam penelitiannya bahwa belum seluruh pengawas sekolah memiliki dan melaksanakan kompetensi seperti yang dipersyaratkan terutama kompetensi penggunaan teknologi internet. Internet merupakan sebuah teknologi di bidang komputer yang dimanfaatkan secara luas (Deborah Fallows, 2004). Melalui teknologi internet, manusia dapat berkomunikasi kapan pun, di mana pun, dan dengan siapa pun (Dahnial Syauqy, dkk.2020 , Guntaro, 2017, Nuris, 2018).

Berkaitan dengan kinerja pengawas sekolah, Arifiatun (2009) mengemukakan bahwa kinerja supervisi yang dilakukan pengawas sekolah belum mempunyai hubungan signifikan terhadap kinerja profesional guru. Hal ini mengindikasikan bahwa kinerja pengawas sekolah dalam pelaksanaan supervisi akademik masih perlu ditingkatkan. Penyebab lain lemahnya kompetensi pengawas adalah minimnya rasio jumlah pengawas dibanding dengan jumlah sekolah yang harus dibina. Hal tersebut berpengaruh pada rendahnya frekuensi pengawas sekolah dalam melaksanakan tugas supervisi ke sekolah binaan mereka, apalagi jika daerah tersebut memiliki letak geografis yang sulit.

Berdasarkan permasalahan tersebut, solusi yang dapat diberikan yaitu dengan melaksanakan pelatihan untuk meningkatkan kompetensi supervise akademik pada aspek penggunaan teknologi internet agar dapat meningkatkan mutu kepala sekolah dan guru dalam melaksanakan tugasnya masing-masing. Melihat keadaan tersebut, maka kami mengadakan kegiatan pemberdayaan bagi para pengawas sekolah melalui pelatihan keterampilan dengan tujuan agar ke depannya mereka lebih professional dalam melaksanakan tugas kepengawasan. Kegiatan ini merupakan salah satu bentuk keterlibatan perguruan tinggi sebagai wujud dari Tridharma Perguruan Tinggi dalam rangka meningkatkan pengetahuan dan keterampilan serta memotivasi pengawas untuk menambah ilmu pengetahuan berkaitan dengan penggunaan internet sebagai salah satu fasilitas yang dapat mempermudah pengawas melaksanakan pekerjaannya.

\section{METODE}

Untuk melaksanakan kegiatan pelatihan dapat dipakai berbagai metode sesuai dengan sasaran yang akan dicapai, agar dalam pemberian materi dapat diserap oleh peserta dengan mudah. Untuk lebih jelas maka berikut ini akan dibahas metode yang digunakan sesuai sasaran dalam pelatihan: Metode ceramah dan tanya jawab digunakan untuk memperkenalkan pengetahuan dan keterampilan yang diberikan. Metode ceramah diberikan ketika menyampaikan materi dan alat yang dipakai serta langkah-langkah yang dilakukan dalam penggunaan teknologi dan komunikasi (TIK). Selanjutnya dilakukan tanya jawab untuk memperdalam materi yang sudah dijelaskan dalam ceramah. Tanya jawab juga berfungsi untuk mengetahui sejauh mana pemahaman peserta terhadap materi yang sudah diberikan.

Selanjutnya, metode yang digunakan dalam pengabdian masyarakat ini adalah metode seminar. Metode seminar adalah suatu kegiatan ilmiah yang dilaksanakan oleh beberapa orang dalam suatu sidang yang membahas/mengupas masalah-masalah atau hal-hal tertentu dalam rangka mencari jalan pemecahannya (solusi) atau pedoman pelaksanaannya. Setelah itu, metode demonstrasi diberikan dalam proses pembuatan akun google masing-masing, penggunaan google drive, dan penggunaan blogs, serta membuat instrumen-instrumen kepengawasan. Kemudian, metode latihan digunakan untuk pembentukan keterampilan peserta dalam penggunaan teknologi internet yang langsung dikerjakan di tempat kegiatan, dibimbing, dan diawasi langsung oleh narasumber, sedangkan metode pemberian tugas dan diskusi 
diberikan kepada peserta untuk mendukung kegiatan yang dilakukan serta terakhir berdiskusi bersama.

Langkah yang dilakukan dalam pelaksanaan program pengabdian masyarakat ini didahului dengan observasi lapangan. Berdasarkan observasi lapangan, ditemukan kendala tentang kurangnya perkembangan teknologi pada sekolah tersebut sehingga kami berupaya meningkatkan kemampuan pendidik dengan melaksanakan workshop pemanfaatan google drive serta pelatihan pembuatan blog. Lalu diadakan pra-pelatihan dengan menjelaskan mengenai google drive serta blog tersebut. Setelah itu dilakukan bagian pelatihan dengan materi mengoperasikan $p c /$ laptop secara bersama-sama dengan membuka google drive serta dasardasar pembuatan blog, kemudian dilakukan evaluasi dan monitoring.

\section{HASIL DAN PEMBAHASAN}

Kegiatan ini berlangsung bulan Agustus 2020 dengan peserta pelatihan adalah pengawas sekolah khususnya pengawas sekolah dasar se-Kota Padang. Dalam pelatihan ini, peserta diberikan penjelasan mengenai rencana dan langkah-langkah kegiatan tim pengabdian masyarakat. Selain memberikan pelatihan, tim pengabdian masyarakat juga berbagi pengalaman tentang pentingnya dan manfaat menggunakan akun google dan pengelolaan blog dalam tugas kedinasan dan kehidupan sehari-hari. Hal ini membuat peserta memahami dan termotivasi untuk mengaplikasikannya dalam keseharian serta membuat peserta menjadi lebih kreatif, aktif, serta interaktif dalam melaksanakan tugas kedinasannya. Dalam setiap kegiatan pelatihan dilakukan interaksi antara tim pengabdian masyarakat dengan para peserta. Interaksi itu berupa presentasi, tanya jawab, dan evaluasi dalam bentuk pengoperasian google drive serta pembuatan blog secara bergantian dan dalam pengawasan.

Hasil pengabdian yang dilakukan berkaitan dengan pelatihan kompetensi supervise akademik pada aspek penggunaan teknologi internet di antaranya kegiatan membantu pengawas sekolah membuat akun google, narasumber memberikan arahan secara langsung kepada para pengawas sekolah, untuk memperlihatkan akun masing-masing yang sudah dimiliki. Bagi yang belum memiliki, dibantu untuk membuat akun google-nya, sehingga setiap pengawas sekolah mempunyai akun google tersebut. Tujuan dari pembuatan akun google adalah untuk memberikan arahan, petunjuk, dan pembelajaran penggunaan serta manfaat dari akun google yang dimiliki kepada pengawas sekolah.

a. Membuat Akun Google

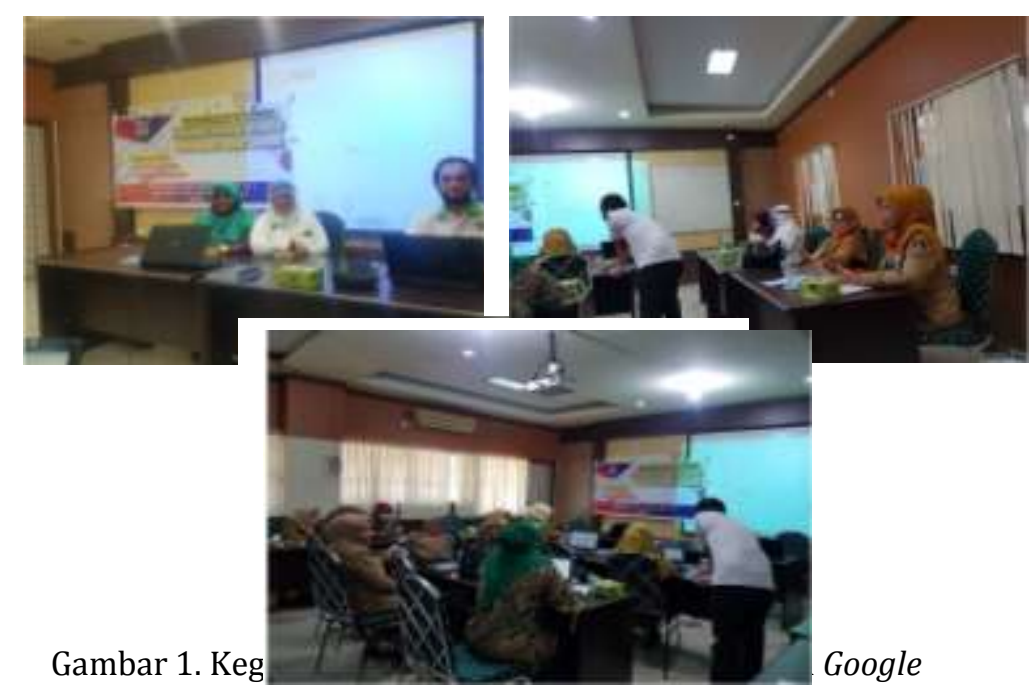




\section{b. Memanfaatkan Google Drive dan Blogs}

Google drive berfungsi untuk menyimpan data dengan kapasitas yang cukup banyak, sehingga data terjaga keamanannya terutama dari virus. Google drive belum banyak yang tahu manfaatnya bagi para pengguna akun google. Google drive ini sangat bermanfaat terutama dalam penyimpanan data dan mempermudah dalam pengoperasiannya. Data di google drive dapat disusun sedemikian rupa sehingga sangat efektif dalam mengelola tugas mandiri apalagi tugas kelompok. Oleh karena itu, perlu diberikan pelatihan kepada para pengawas sekolah bagaimana memanfaatkan google drive untuk menyimpan data atau file-file yang penting, berharga, dan rahasia.

Dalam dunia pendidikan blog merupakan media yang sangat mendukung untuk proses belajar mengajar karena menggunakan blog memudahkan guru dalam memberikan tugas terhadap siswa. Manfaat bagi siswa, blog dapat membantu menyalurkan kreativitas menulisnya. Blog dapat memudahkan siapa pun yang ingin mendapatkan informasi tanpa harus bersusah payah mencari buku, hanya bermodal internet siapa pun dapat mencari informasi apa pun di dalam blog. Manfaat lainnya dengan adanya blog adalah siswa tidak gagap akan teknologi. Menurut Sujana dkk. [2002:2] beberapa manfaat media/blogs pembelajaran adalah sebagai berikut: (a) Pembelajaran akan lebih menarik perhatian siswa sehingga dapat menumbuhkan motivasi, (b) Bahan pengajaran akan lebih jelas maknanya sehingga lebih dipahami oleh siswa dan memungkinkannya menguasai tujuan pengajaran lebih baik.
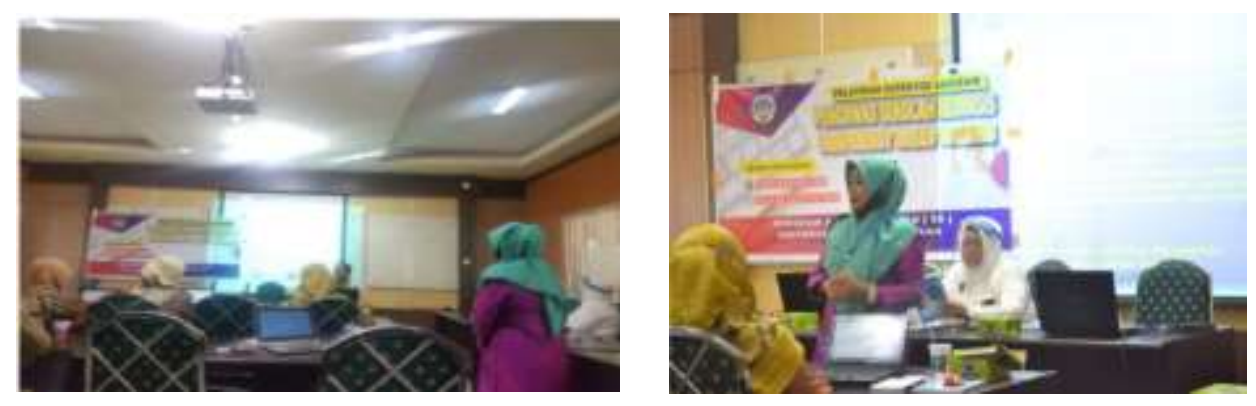

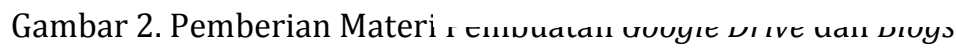

Secara umum kegiatan ini dapat dikatakan berhasil, terindikasi dengan banyaknya tanggapan positif dari peserta dan lingkungan sekolah tentang adanya kegiatan pelatihan yang diselenggarakan. Hal ini juga ditunjukkan dari sikap instansi sekolah, khususnya kepala sekolah dan para guru yang sangat mengharapkan kegiatan ini tidak hanya dilakukan sekali, namun dapat dilakukan secara rutin.

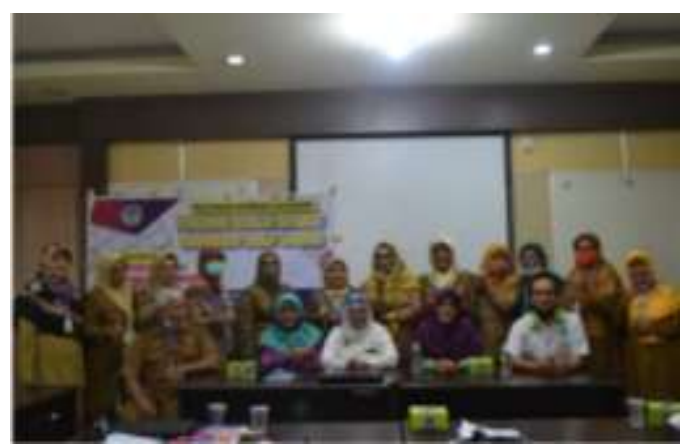

Gambar 3. Foto Bersama Peserta Pelatihan 


\section{KESIMPULAN}

Dari hasil pelatihan yang sudah dilakukan, diperoleh kesimpulan bahwa peserta mendapatkan pengetahuan tentang google drive dan blog, cara pengoperasian google drive serta blog, cara menambahkan data, pola penyimpan data, serta pengelolaan data secara mudah dan efisien, dan yang tidak kalah pentingnya adalah tim pengabdian pada masyarakat dapat memotivasi peserta tentang pentingnya melek TIK di era digital sekarang ini.

\section{UCAPAN TERIMA KASIH}

Terimakasih dan penghargaan kepada semua pihak yang telah ikut berpartisipasi dalam pelaksanaan pengabdian pada masyarakat ini, terutama kepada Lembaga Penelitian dan Pengabdian Masyarakat UMSB.

\section{DAFTAR PUSTAKA.}

Dahnial Syauqy, dkk. 2020. Peningkatan Kompetensi Keilmuan IOT Melalui Pelatihan Pengontrolan Perangkat IOT dengan Menggunakan Smartphone untuk Siswa SMK danSMA di Kota Malang. Jurnal Dinamisia Vol.4 No 3 September 2020

Deborah Fallows. (2004). The Internet and Daily Life I Pew Research Center. Pew Research Center. https://www.pewresearch.org/internet/2004/08/11/the-internet-and-dailylife/\%0Ahttp://www.pewinternet.org/2004/08/11/the-internet-and-daily-life/

Eko, (2013). Membangun blog bisnis di Internet. Jakarta: Penerbit Elex Media Komputindo

Guntoro, G., Costaner, L., \& Sutejo, S. (2017). Pelatihan Sistem Pembelajaran E-Learning pada Sekolah Menengah Kejuruan Dwi Sejahtera Pekanbaru. Dinamisia : Jurnal Pengabdian Kepada Masyarakat. https://doi.org/10.31849/dinamisia.v1i1.411.

Ismawan Fiqih, Puput Irfansyah, Dwi Dani A. (2017), Jurnal PKM, LPPM Universitas Indraprasta PGRI, Vol 1 No. 1 Januari 2018, http://journal.lppmunindra.ac.id/ind ex.php/pkm/article/view/2362. Diakses pada 10 Mei 2018

Nuris, D. M. (2018). Pelatihan Penyusunan Perangkat Pembelajaran Berbasis TIK Bagi Guru Akuntansi SMK. Dinamisia : Jurnal Pengabdian Kepada Masyarakat. https://doi.org/10.31849/dinamisia.v2i2.1819

Puput Irfansyah, dkk. (2018). Pemanfaatan Media Pembelajaran Dan Penyimpanan Dokumen Online Menggunakan Blog Dan Gdrive Untuk Guru. Seminar Nasional dan Diskusi Panel Multidisiplin Hasil Penelitian \& Pengabdian kepada Masyarakat, Jakarta, 2 Agustus 2018

Uus Ruswenda (2011). Berbagai Faktor Dalam Supervisi Akademik Pengawas Sekolah Menengah Kejuruan (SMK) Di Kabupaten Kuningan. Tesis.Jakarta: Fakultas Ilmu Sosial dan Ilmu Politik Program Studi IlmuAdministrasi Kekhususan Administrasi dan Kebijakan Pendidikan. Universitas Indonesia.

Sudjana, Nana dan Ahmad Rivai. (2002). Media Pengajaran. Bandung: Sinar Baru Algesindo.

Winarno, ST.E, Ali, Z. and SmitDev, C, (2013). Step By Step Aplikasi Google Apps. Semarang: Elex Media Komputindo 